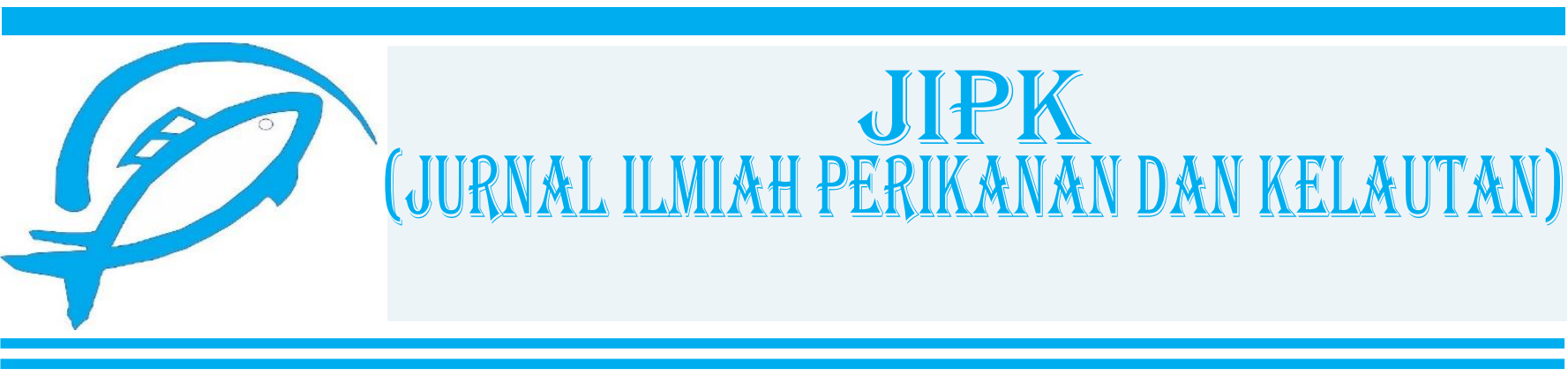

Short Communication

\title{
The Difference in Lactobacillus plantarum Density on the Fermentation Process of Cassava Leaves (Manihot utillisima) as Substance for Plant-Based Protein
}

\section{Priyandaru Agung Eko Trapsilo ${ }^{1 *}$ (D), Anik Martinah Hariati ${ }^{2}$ and Titik Dwi Sulistiati ${ }^{3}$}

${ }^{1}$ Program Study of Aquaculture, Faculty of Fisheries and Marine Science, University of Brawijaya, Malang, East Java, 65145. Indonesia

${ }^{2}$ Department of Water Resources Management, Faculty of Fisheries and Marine Science, Universityof Brawijaya, Malang, East Java, 65145. Indonesia

${ }^{3}$ Department of Fisheries Technology, Faculty of Fisheries and Marine Science, University of Brawijaya, Malang, East Java, 65145. Indonesia

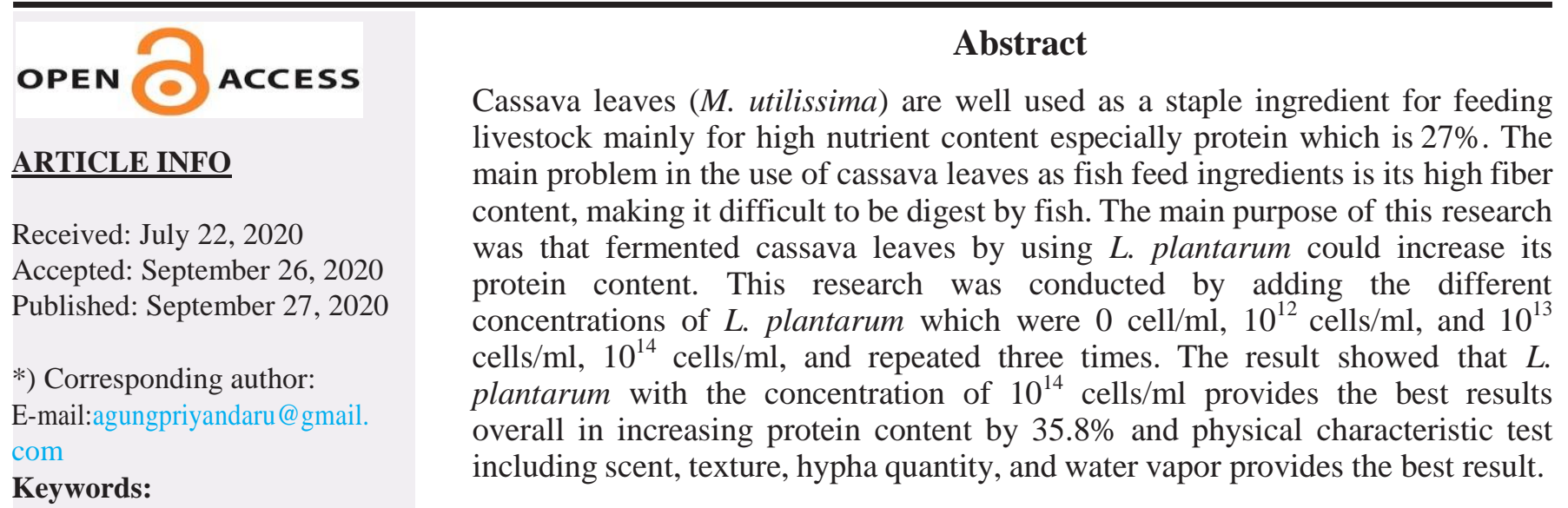

Protein

Fish feed

Physical characteristic

This is an open access article under the CC BY-NC-ND license (http://creativecommons.org/licenses/by-nc-nd/4.0/)

Cassava leaves (M. utilissima) are well used as a staple ingredient for feeding livestock mainly for high nutrient content especially protein which is $27 \%$. The main problem in the use of cassava leaves as fish feed ingredients is its high fiber content, making it difficult to be digest by fish. The main purpose of this research was that fermented cassava leaves by using L. plantarum could increase its protein content. This research was conducted by adding the different concentrations of $L$. plantarum which were 0 cell $/ \mathrm{ml}, 10^{12}$ cells $/ \mathrm{ml}$, and $10^{13}$ cells $/ \mathrm{ml}, 10^{14}$ cells $/ \mathrm{ml}$, and repeated three times. The result showed that $L$. overall in increasing protein content by $35.8 \%$ and physical characteristic test including scent, texture, hypha quantity, and water vapor provides the best result.

Cite this as: Trapsilo, P. A. E., Hariati, A. M., \& Sulistiati, T. D. (2020). The Difference in Lactobacillus plantarum Density on the Fermentation Process of Cassava Leaves (Manihot utillisima) as Substance for Plant-Based Protein. Jurnal Ilmiah Perikanan dan Kelautan, 12(2):324-329. http://doi.org/10.20473/jipk.v12i2.22183. 


\section{Introduction}

Cassava leaves (Manihot utilissima) are one of main ingredient for feed alternatives that has maximum nutritional value, and valuable for fish farming especially to increase digestive enzyme activity, nutrient efficiency, growth, economical, and abundant to be obtained. Main ingredients are categorized as protein sources if it contains more than $18 \%$. While cassava leaves has raw protein content of $27 \%$ which is suitable for carnivorous and herbivorous fish. Cassava leaves has amino acid content including lysine $(2.00 \%)$ and methionine $(0.40 \%)$. Ratio of amino acid lysine to protein in cassava leaves flour are $(7.4 \%)$ which is equal to the value on fish flour $(7.7 \%)$ and higher than soybean meal $(6.30 \%)$ (Askar, 2006). Cassava leaves (M. utilissima) are very good for use as raw material for human food and animal feed because cassava leaves contain very high levels of vitamin A, vitamin C, minerals (Fe, Ca), and protein (OECD, 2009). Hence, cassava leaves can be one of protein sources in fish feed and capable of alternative sources for livestock staple food. Unfortunately, the fiber in cassava leaves are too complex to be digested by fish and its $\mathrm{HCN}$ (anti nutrition) content can interfere the growth of fish so that it needs to be break down to be able to digest by fish in cultivation. This substance is a covalent molecular substance that can dissociate in water, and is a very poisonous and colorless gas. This type of substance is a strong poison that will cause asphysics (hypoxia) and hinder with oxidation (transport of $\mathrm{O}_{2}$ ) to body systems by binding to oxidative cytochrome enzymes. This bond cannot be used by the tissue so that organs that require more oxygen will be damaged, especially brain system which can be seen from the central nervous system which will be followed by stress levels that lead to seizures by hypoxia to death caused by respiratory problems (DHHS, 2006). The dosage that can be lethal in the use of cyanide is 3 $\mathrm{mg} / \mathrm{kg}$. As for how to improve the nutritional quality of an ingredient so that it is easily absorbed and digested by fish is by carrying out a fermentation process that utilizes microorganisms as a medium during the fermentation process. Then, to reduce the anti nutrition in cassava leaves, it need to carrying out boiling process before it used to main ingredient of fish feed (Rawat, 2015).

One of the microorganisms that is often used in the fermentation process is the type of $L$. plantarum. This type of bacteria is gram positive, facultative anaerobic rods. This Lactobacillus bacteria is a genus of a group of lactic acid bacteria (LAB) that live in the digestive tract and play a role in the process of food fermentation (Puspadewi et al., 2011). One of the important in the application of lactic acid bacteria for fermentation process is the ability of these bacteria to produce bacteriocin to inhibit the growth of various pathogenic bacteria (Aliya et al., 2016). It has antagonistic properties against microorganisms that cause food degradation such as Salmonella, Staphylococcus aureus, Gram negative. These bacteria are salt tolerant bacteria, that can produce acid quickly and have an ultimate $\mathrm{pH}$ of 5.3 to 5.6 (Buckle et al., 1985). Bacteriocin produced by lactic acid bacteria functions as an anti bacterial, it will make balance in fish digestibility so that the digestive tract of fish becomes better at digesting and absorbing nutritious food (Purba, 2017). The feed that use Lactobacillus bacteria can increase growth, immune response, and disease resistance in the Ephinephelus coioides, Ephinephelus bruneus, and tilapia (Oreochromis nilloticus) groups (Abumourad et al., 2013). This research's main focus is to give solution for fish farmer to utilize the cassava leaves as main ingredient in alternative fish feed which has high protein to increase fish growth.

\section{Materials and Methods}

\subsection{Cassava Leaves Fermentation}

Cassava leaves are cleansed by using running water. Boiling is carried out to reduce levels of anti-nutrient substances in cassava leaves. After boiling there was reduction in the anti nutrional composition such as nitrate and tannin (Lola, 2009). Next is to dry the leaves under sunlight two days and for 7 hours. Dried cassava leaves are mashed using a diskmill, sifted then weighed and put into plastic. Flour that has been added to the plastic then added $L$. plantarum bacteria as much as $1.5 \%$ in the leaves to be fermented (Dewi et al., 2010) by being given a density treatment that is $10^{12}$ cells $/ \mathrm{ml}, 10^{13}$ cells/ $\mathrm{ml}, 10^{14}$ cells $/ \mathrm{ml}$. The bacteria counted by Optical Density (OD) and Total Plate Count (TPC) methods. It used to the different dilution in the test tube so it could be decided the density of $10^{1}$ cell $/ \mathrm{ml}$ until $10^{14}$ cells $/ \mathrm{ml}$ Then bacteria was planted in Nutrient Agar (NA) during a day, and counted the density level by regression score. Then added molase as much as $2,5 \mathrm{~kg} / 100 \mathrm{~kg}$ and put in a closed box in an anaerobic state. The process are checked on the $7^{\text {th }}$ day, $14^{\text {th }}$ day, and $21^{\text {st }}$ day.

\subsection{Physical Characterization}

The method was used in the study physical characteristic organoleptic which made on the fermentation process are changes in texture, aroma, 
JIPK. Volume 12 No 2. November 2020 / The Difference in Lactobacillus plantarum Density on the Fermentation Process of ....

amount of hyphae, amount of water vapor on the surface of fermented cassava leaves (Sukardi et al., 2008) then made in the form of scoring to show the success of the fermentation process at each treatment with the density of $L$. plantarum used which were 0 cell $/ \mathrm{ml}, 10^{12}$ cells $/ \mathrm{ml}, 10^{13}$ cells $/ \mathrm{ml}, 10^{14}$ cells $/ \mathrm{ml}$. Score range between 1-4 to determine quality where the higher the score implies better fermentation.

\subsection{Proximate Analysis}

Proximate analysis was carried out on cassava leaves before and after fermentation with the density of L. plantarum used, namely 0 cell $/ \mathrm{ml}, 10^{12}$ cells $/ \mathrm{ml}, 10^{13}$ cells $/ \mathrm{ml}, 10^{14} \mathrm{cells} / \mathrm{ml}$. Proximate analysis is carried including protein, fat, water, and ash contents, crude fiber, and BETN.

\subsection{Statistical Analysis}

The data was analyzed by using the SPSS version 16.0 program with one way ANOVA test. The analysis is used to test the effect of treatment, followed by using the least significant difference test (LSD) with the Duncan test method. From this test continued with orthogonal polynomial analysis to determine the response test (AOAC, 1995).

\section{Results and Discussion}

Cassava leaves fermentation scoring result are shown based on following graphics on Figure 1. From the scoring graph on Figure 1 obtained the best $L$. plantarum dose and fermentation time is density of $10^{14}$ cells/ml within 21 days. It is obtained from observations of physical characteristics such as aroma, texture, amount of hyphae, water vapor that observed in the fermentation process. From the observation on $7^{\text {th }}$ day, cassava leaves texture had raw leave surfaces and faded easily. However on $14^{\text {th }}$ day, it had few lumps in $10^{12}$ cells $/ \mathrm{ml}$ and $10^{13}$ cells $/ \mathrm{ml}$ dose. The most lumps was found in $10^{14}$ cells $/ \mathrm{ml}$ dose started on $14^{\text {th }}$ until $21^{\text {st }}$ day.

The lowest of number of Hyphae had result in $10^{14}$ cells/ml dose. The small amount of hyphae that surrounds the fermentation of cassava leave is caused by $L$. plantarum having antifungal properties. The antifungal ability produced by LAB produces bioactive compounds produced in the form of hydrogen peroxide, diacetyl, and bacteriocin which work antagonistically against pathogenic, and hyphae bacteria. Antipatogen compounds found in LAB in the form of proteins, proteins produced by L. plantarum in the form of cyclo cyclic dipeptides which can inhibit mold growth (Strom et al., 2002).

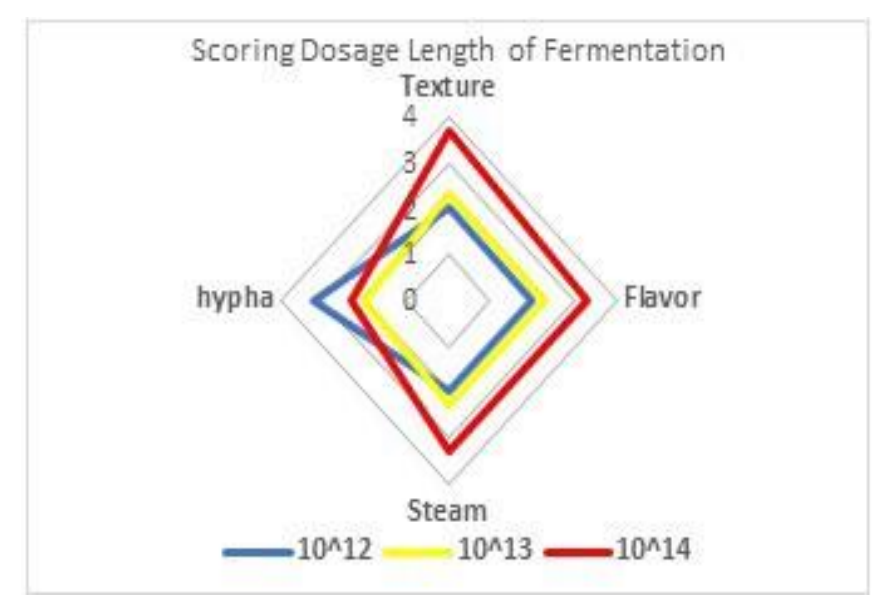

Figure 1. Fermentation duration score result

Fresh and fragrant aromas produced from all treatments with fermentor bacteria are good quality silage characteristics. This is influenced by the fermentation process that produces lactate acid (Zakariah et al., 2015). During the fermentation process, LAB type bacteria produce enzymes in degrade the substrate, one of them enzymatic processes during the fermentation process. Enzymes broke the fat and protein to release a fragrant fermentation. It produced from lactic acid excretion that released organic acid. The substance had released by lactic acid bacteria and volatil component built acid and characteristics aroma (Edam, 2018). The presence of enzymes when lactic acid bacteria in the fermentation process will be able to change the texture, aroma, taste, and increase the nutritional value (Suri et al., 2013). Table 1 shows the scoring percentage in or- ganoleptic process.

The results of cassava leaves that have been fermented with the best fermentation results carried out the density of $L$. plantarum bacteria that is $10^{14} \mathrm{cell} / \mathrm{s} / \mathrm{ml}$ within 14 days. The use of fermentation is intended to reduce levels of crude fiber, and improve protein quality. The results can be seen in Table 2. The results of the proximate fermentation analysis presented in Table 2 show that fermentation using $L$. plantarum can increase protein levels in fermented cassava leaves. The highest level of protein testing occurred at the use of $10^{14} \mathrm{cells} / \mathrm{ml}$ bacteria which produced a protein content of $35.87 \%$, then followed by the use of $10^{12}$ cells $/ \mathrm{ml}$ bacteria $(26.23 \%)$, and $10^{13}$ cells $/ \mathrm{ml}(26.96 \%)$. While the lowest protein content results are shown in leaves without fermentation using L. plantarum. Increased protein levels during the fermentation process using LAB is caused because during the fermentation process $\mathrm{LAB}$ will produce peptidoglycan compounds found in cell walls, which are known to be composed of lipoprotein and glycoprotein components (Reddy et al., 2008). 
Table 1. Scoring criteria for physical tests on fermentation

\begin{tabular}{|c|c|c|c|c|c|}
\hline $\begin{array}{l}\text { Score } \\
\text { Value }\end{array}$ & Status & Number of Lumps & Aroma & $\%$ Vapor & $\begin{array}{c}\text { Number of } \\
\text { Hyphae }\end{array}$ \\
\hline 1 & $\begin{array}{l}\text { Very } \\
\text { Poor }\end{array}$ & Soft $<10 \%$ & Rancid $>40 \%$ & Dry $<10 \%$ & None $<10 \%$ \\
\hline 2 & Poor & $\begin{array}{l}\text { Slight Lump } \\
<10-<25 \%\end{array}$ & $\begin{array}{l}\text { Slight Rancid } \\
>25-<40 \%\end{array}$ & $\begin{array}{l}\text { Slightly humid } \\
<10-<25 \%\end{array}$ & $\begin{array}{c}\text { Small } \\
<10-<25 \%\end{array}$ \\
\hline 3 & Good & $\begin{array}{c}\text { Moderate } \\
>25-<40 \%\end{array}$ & $\begin{array}{c}\text { Slight Fragrant } \\
>10-<25 \%\end{array}$ & $\begin{array}{l}\text { Moderate } \\
\text { Amount } \\
>25-<40 \%\end{array}$ & $\begin{array}{c}\text { Moderate } \\
>25-<40 \%\end{array}$ \\
\hline 4 & $\begin{array}{c}\text { Excellen } \\
\mathrm{t}\end{array}$ & Abundant $>40 \%$ & Fragrant $<10 \%$ & Abundant $>40 \%$ & Abundant $>40 \%$ \\
\hline
\end{tabular}

Table 2. Proximate analysis of cassava leaves fermentation

\begin{tabular}{|c|c|c|c|c|c|c|}
\hline $\begin{array}{c}\text { Bacteria } \\
\text { Dosage }\end{array}$ & Protein (\%) & Fat (\%) & $\begin{array}{c}\text { Water } \\
(\%)\end{array}$ & Ash (\%) & $\begin{array}{c}\text { Crude } \\
\text { Fiber (\%) }\end{array}$ & $\begin{array}{c}\text { Carbohydra } \\
\text { te }(\%)\end{array}$ \\
\hline 0 cell $/ \mathrm{ml}$ & $24,92 \pm 0,57^{\mathrm{a}}$ & $6,57 \pm 0,51^{\mathrm{a}}$ & $\begin{array}{l}92,04 \\
\pm 0,65^{\mathrm{a}}\end{array}$ & $9,77 \pm 0,61^{a}$ & $26,56 \pm 0,6^{a}$ & $32,18 \pm 1,12^{\mathrm{a}}$ \\
\hline $10^{12} \mathrm{cell} / \mathrm{ml}$ & $26,96 \pm 0,72^{\mathrm{a}}$ & $6,52 \pm 0,66^{a}$ & $\begin{array}{l}92,54 \\
\pm 0,57^{\mathrm{a}}\end{array}$ & $\begin{array}{l}11,68 \\
\pm 0,70^{\mathrm{b}}\end{array}$ & $\begin{array}{l}29,21 \\
\pm 0,54^{\mathrm{a}}\end{array}$ & $25,63 \pm 1,15^{\mathrm{a}}$ \\
\hline $10^{13} \mathrm{cell} / \mathrm{ml}$ & $26,23 \pm 0,50^{\mathrm{a}}$ & $7,74 \pm 0,57^{a}$ & $\begin{array}{l}92,73 \\
\pm 0,59^{\mathrm{a}}\end{array}$ & $\begin{array}{c}9,72 \\
\pm 0,59^{\mathrm{ab}}\end{array}$ & $\begin{array}{l}22,10 \\
\pm 0,60^{\mathrm{a}}\end{array}$ & $34,21 \pm 1,98^{\mathrm{a}}$ \\
\hline $10^{14} \mathrm{cell} / \mathrm{ml}$ & $35,87 \pm 0,74^{b}$ & $5,74 \pm 0,33^{a}$ & $\begin{array}{l}91,75 \\
\pm 0,39^{\mathrm{a}}\end{array}$ & $8,62 \pm 0,39^{\mathrm{a}}$ & $18,33 \pm 1,07^{\mathrm{a}}$ & $31,44 \pm 1,07^{\mathrm{a}}$ \\
\hline
\end{tabular}

The proximate analysis used $L$. plantarum increased protein, fat, carbohydrate, and energy. While the fermentation process, $\mathrm{CO}_{2}$ and $\mathrm{H}_{2} \mathrm{O}$ was released caused the breaked out of organic compound in fermentation media. Fermentation process used to increase the feed digestibility through the breaked out complex organic compound including carbohydrate, fat, protein, and other organic compound (Sahlin, 1999). Gunawan (2015) had studied the fermentation of cassava leaves within different time of fermentation which used lactic acid bacteria was result that increased protein $8 \%$ than before fermentation. One of the bacteria that could be used to increased protein to $8.52 \%$ is $L$. Plantarum. It was caused by bacteria released some extracellular enzyme such as proteinase.

\section{Conclusion}

Conclusion from the results showed that the fermentation of cassava leaf flour by using $L$. plantarum bacteria at a density of $10^{14}$ cells $/ \mathrm{ml}$ gave the best results in increasing the protein content by $35.87 \%$ and the physical characteristics test in the form of aroma, texture, amount of hyphae, water vapor gave the best results.

\section{Acknowledgment}

Mrs. Dr. Ir. Anik Martinah Hariati, M.Sc as the head of the Advisory committee and Dr. Ir. Titik Dwi Sulistiati, MP as a member of the advisory commission, who always provides a lot of suggestions, direction, advice and has been patient when guiding me, starting 
from the preparation of the proposal to the final of this thesis report.

\section{Authors' Contributions}

I would like to thank to Prive Widya Antika and Endar Riyani who helped in completing this research in laboratory and literature studies. For Dedi who has helped and taught in statistical data processing of this research. For Siti Lestari who has been directed the conceptual in this research.

\section{Conflict of Interest}

The authors declare that they have no competing interests.

\section{Funding Information}

This thesis research is done by using personal costs to fulfill the graduation of Universitas Brawijaya Post graduate Course.

\section{References}

Abumourad, I. M. K., Abbas, W. T., Awaad, E. S., Authman, M. M. N., El-Shafei, K., Sharaf, O. M., Ibrahim, G. A., Sadek, Z. I., \& El-Sayed, H. S. (2013). Evaluation of Lactobacillus plantarum as a probiotic in aquaculture: emphasis on growth performance and innate immunity. Journal of Applied Sciences Research, 9(1): 572-582.

Aliya, H., Maslakah, N., Numrapi, T., Buana, A. P., \& Hasri, Y.N. (2016). Pemanfaatan asam laktat hasil fermentasi limbah kubis sebagai pengawet anggur dan stroberi. Bioedukasi, 9(1): 23-28.

AOAC (Association of Official Analytical Chemists). (1995). Official methods of analysis, 12th Ed. Washington DC

Askar, S. (2006). Daun singkong dan pemanfaatannya terutama sebagai pakan tambahan. Bogor: Balai Penelitian Ternak. pp. 21-25.

Buckle, K. A., Edwards, R. A., Fleet, G. H., \& Wooton, M. (1985). Ilmu pangan. Penerjemah: $H$. Purnomo \& Adiono. Jakarta: Penerbit Universitas Indonesia.

Dewi, S. R., Huda, N., Ahmad, R., \& Abdullah, W. N. W. (2010). Mutu protein dendeng ikan hiu yang diolah. Jurnal Pascapanen dan Bioteknologi Kelautan dan Perikanan, 5(1): 87-92.

DHHS (Department of Health and Human Services). (2006). Toxicological profile for cyanide. U.S. Department of Health and Human Services. Public Health Service. Atlanta, Georgia: Agency for Toxic Substances and Disease Registry.

Edam, M. (2018). Variasi lama fermentasi dengan penambahan $\mathrm{NaCl}$ terhadap produksi asam laktat dari kubis (Brassica oleracea). Jurnal Penelitian Teknologi Industri, 10(1): 25-36.
Gunawan, S., Widjaja, T., Zullaikah, S., Ernawati, L., Istianah, N., Marta, H., \& Prasetyoko, D. (2015). Effect of fermenting cassava with Lactobacillus plantarum, Saccharomyces cereviseae, and Rhizopus oryzae on the chemical composition of their flour. International Food Research Journal, 22(3): 1280-1287.

Lola, A. (2009). The effect of boiling on the nutrients and anti nutrients in two non conventional vegetables. Pakistan Journal of Nutrition, 8(9): 1430-1433

OECD. (2009). Environment directorate joint meeting of the chemicals committe and the working party on chemicals, pesticides and biotechnology. Series on the Safety of Novel Foods and Feeds No. 18. 50p.

Purba, R. U., Adelina. \& Suharman, I. (2017). The utilization of feather meal fermented using bacillus sp. from tiger shrimp (Penaeus monodon) for fish feed of silver pompano (Tracchinotus blochii) fingerling. Jurnal Online Mahasiswa Perikanan dan Ilmu Kelautan Universitas Riau, 4(2): 1-9.

Puspadewi, R., Adirestuti, P., \& Anggraeni, G. (2011, Juni). Aktivitas metabolit bakteri Lactobacillus plantarum dan perannya dalam menjaga kesehatan saluran pencernaan. Konferensi Nasional Sains dan Aplikasinya, 1-10.

Rawat, K., Nirmala, C., \& Bisht, M. S. (2015). Processing techniques for reduction of cyanogenic glycosides from bamboo shoots. $10^{\text {th }}$ World Bamboo Congress, Korea, 12p.

Reddy, G., Altaf, M., Naveena, B. J., Venkateshwar, M., \& Kumar, E. V. (2008). Amylolytic bacterial lactic acid fermentation A review. Biotechnology Advances, 26(1): 22-34.

Sahlin, P. (1999). Fermentation as a method of food processing production of organic acid, $\mathrm{pH}$ development and microbial growth in fermenting cereals. Licentiate Thesis. Lund, Sweden: Lund Institute of Technology. Lund University.

Strom, K., Sjögren, J., Broberg, A., \& Schnürer, J, (2002). Lactobacillus plantarum MiLAB 393 produces the antifungal cyclic dipeptides cyclo (L-Phe-L-Pro) and cyclo (L-Phe-trans-4-OH-LPro) and 3-phenyllactic acid. Applied Environment. of Microbiology, 68(9): 4322-4327.

Sukardi, Wignyanto, \& Purwaningsih, I. (2008). Tempeh inoculum application test of Rhizopus oryzae with rice and cassava flour as substrate at Sanan Tempeh Industries Kodya Malang. Jurnal Teknologi Pertanian, 9(3): 207-215.

Suri, W. L., Syukur, S., \& Jamsari. (2013). Optimization of protease activity from lactic acid bacteria (Lab) Pediococcus pentosaceus isolated from soursop fermentation (Annona muricata L.). Jurnal Hasil Riset, 2(1): 2303-3401. 
Trapsilo et al. / JIPK, 12 (2): 324-329

Zakariah, M. A., Utomo, R., \& Bacruddin, Z. (2015). Pengaruh inokulum campuran Lactobacillus plantarum dan Saccharomyces cerevisiae terhadap kualitas organoleptik, fisik, dan kimia silase kulit buah kakao. Buletin Peternakan, 39(1):1-8. 